\title{
Harmony, Law and Criminal Reconciliation in China: A Historical Perspective
}

\author{
Wei Pei*
}

\begin{abstract}
In 2012, China revised its Criminal Procedure Law (2012 $\mathrm{CPL}$ ). One of the major changes is its official approval of the use of victim-offender reconciliation, or 'criminal reconciliation' in certain public prosecution cases. This change, on the one hand, echoes the Confucian doctrine that favours harmonious inter-personal relationships and mediation, while, on the other hand, it deviates from the direction of legal reforms dating from the 1970s through the late 1990s. Questions have emerged concerning not only the cause of this change in legal norms but also the proper position of criminal reconciliation in the current criminal justice system in China. The answers to these questions largely rely on understanding the role of traditional informal dispute resolution as well as its interaction with legal norms. Criminal reconciliation in ancient China functioned as a means to centralise imperial power by decentralizing decentralising its administration. Abolishing or enabling such a mechanism in law is merely a small part of the government's strategy to react to political or social crises and to maintain social stability. However, its actual effect depends on the vitality of Confucianism, which in turn relies on the economic foundation and corresponding structure of society.
\end{abstract}

Keywords: Criminal reconciliation, Confucianism, decentralisation, centralisation

\section{Introduction}

Scholarship on the relationship between legal norms and social norms is flourishing. Over the past few decades, a number of publications have appeared on diverse topics. ${ }^{1}$ This article intends to contribute to this scholarly debate by exploring the interaction between legal and social norms in the topic of criminal reconciliation in China.

Why criminal reconciliation? One widespread view holds that the maintenance of harmonious relationships between disputants by way of private mediation, even in the criminal context, has long been prized by traditional Chinese culture. ${ }^{2}$ Such a cultural foundation should (and did in ancient times) encourage the legislator to codify mediation in written law. However, since the end of the Qing Dynasty in the early 1900s, modernisation of the Chinese criminal justice system has resulted in the reduction of private dispute resolution proceedings (particularly mediation), on the one hand, and the rise of formal criminal proceedings featuring public confrontation, on the other.

Does this trend in legal norms indicate a gradual weakening in the influence of traditional mediation in solving criminal cases? This question is difficult to answer, especially when one takes the 2012 Criminal Procedure Law (2012 CPL) into consideration. After the Cultural Revolution (1966-1976), three versions of the CPL have been enacted. Both the 1979 CPL and its 1996 revision

1. M. Edwards, 'The Law and Social Norms of Pay Secrecy', 26 Berkley Journal of Employment and Labor Law 41 (2005) (civil and commercial law); E. Scott, 'Social Norms and the Legal Regulation of Marriage', 86 Virginia Law Review 1902 (2000) (marriage law); E. Posner, 'Law and Social Norms: The Case of Tax Compliance', 86 Virginia Law Review 1781 (2000) (tax law); M. Eisenberg, 'Corporate Law and Social Norms', 99 Columbia Law Review 1253 (1999) (corporate law); R. Cooter, 'Punitive Damages, Social Norms, and Economic Analysis', 60 Law \& Contemporary Problems 73 (1997) (punitive damages); D. Kahan, 'What Do Alternative Sanctions Mean?', 73 The University Chicago Law Review 1 (1996) (criminal sanction); L. Bernstein, 'Merchant Law in a Merchant Court: Rethinking the Code's Search for Immanent Business Norms', 144 University Pennsy/vania. Law Review 1765 (1996) (contract and commercial law); R. Ellickson, Order without Law: How Neighbors Settle Disputes (1991) (about civil dispute resolution).

2. See e.g. X. Zeng, 'Mediation in China - Past and Present', 17 Asia Pacific Law Review 1 (2009) (about the historical roots of mediation); G. Chen, Law without Lawyers, Justice without Courts: On Traditional Chinese Mediation (2002) (about the cultural roots of mediation and its litigation-averse nature); P. Huang, 'Between Informal Mediation and Formal Adjudication', 19 Modern China 251 (1993) (about medication in civil justice in Qing Dynasty); E. Glassman, 'The Function of Mediation in China: Examining the Impact of Regulations Governing the People's Mediation Committees', 10 UCLA Pacific Basin Law Journal 460 (1991) (about the semi-official mediation institution PMC); S. Lubman, Mao and Mediation: Politics and Dispute Resolution in Communist China (1967) (about the political function of mediation during Mao's period); J. Cohen, 'Chinese Mediation on the Eve of Modernization', 54 California Law Review 1201, at 1201 (1966) (about the coordination between traditional mediation and Mao's communism). 
seemed to follow the trend of marginalising forms of private dispute resolution. However, in the 2012 revision, victim-offender mediation is recognised as a special procedure to solve two categories of public prosecution cases. ${ }^{3}$ The first category refers to cases caused by disputes between civilians, falling into crimes stipulated in Chapters 4 and 5 of the 1997 Criminal Law (1997 $\mathrm{CL}$ ), and with a maximum sentence lower than three years' imprisonment. The second category includes negligent crimes with a maximum sentence lower than seven years' imprisonment, except for duty-related crimes. ${ }^{4}$

Thus, the following questions emerge. Why has the legislator's attitude towards criminal reconciliation been more favourable in certain time periods than others? Can similar changes in social preferences regarding private dispute resolution be observed? If not, how can the divergence and convergence between social norms and law be explained? More importantly, what should be the proper position of criminal reconciliation in the current criminal justice system in China? All in all, why has criminal reconciliation come back and how does it come back? Answers to these questions largely rely on understanding the evolution of social norms as well as their interaction with legal norms. This article follows Feeley's (1976) definition to a large degree. Feeley describes a legal norm as 'a command or order [issued by competent state authority and properly published] to do or refrain from doing some specified act(s), and is ... [enforceable] by the threat of physical coercion attached

3. China still preserves private prosecution in certain situations. According to the $2012 \mathrm{CPL}$, private prosecution can be applied to three situations under the $1997 \mathrm{CL}$ : (1) cases to be handled only upon individual complaint, including insult and slander (Art. 246), violent interference with the freedom of marriage (Art. 257), abuse (Art. 260) and normal embezzlement (Art. 270); (2) minor criminal cases that the victims must have evidence to prove, including eight kinds of crimes under $1997 \mathrm{CL}$ : intentional injury (para. 1, Art. 234), intrusion (Art. 245), infringing the right of communication (Art. 252), bigamy (Art. 258), abandonment (Art. 261), infringement of intellectual property rights (Section 1 in Chapter 3), manufacturing and selling fake and shoddy goods (Section 1 in Chapter 3) and crimes within Chapters 4 and 5 for which a sentence of less than three years' imprisonment may be imposed; and (3) cases for which the victims have evidence to prove that the defendants, who infringed the victim's personal or property rights, should be investigated, whereas the PSO or the public procuratorate refuses to investigate. The purpose of the third type of case, which is distinguished from the former two, is to provide remedy to the victims when the state machinery fails to function, and its nature is a limitation on judicial discretion. Thus, only in the former two types may parties have their cases reconciled either by victims withdrawing prosecution, or by the people's court recognising the reconciliation agreement. Private prosecution cases only account for a very small proportion of the entire criminal caseload.

4. For detailed introduction of the legal regime of criminal reconciliation under the 2012 CPL, see W. Pei, 'Criminal Reconciliation in China: Consequentialism in History, Legislation, and Practice', 3 China-EU Law Journal 191 (2014). Some scholars have also discussed the application of criminal reconciliation in death penalty, but it is mainly based on practice before the 2012 CPL. The 2012 CPL prescribes the scope of reconcilable cases, and this article relies on that scope. See R. Weatherley and H. Pittam, 'Money for Life: The Legal Debate in China About Criminal Reconciliation in Death Penalty Cases', 39 Asian Perspective 277 (2015). to the order'. 'Social norms', in contrast, are 'informal societal constraints that are generally not enforceable under law'. ${ }^{6}$ Two major distinctions between legal norms and social norms are the pro forma distinction with respect to legislative procedure and legal forms and the substantial distinction regarding enforceability. In this article, 'legal norm' is interchangeable with 'law', while 'social norm' generally equals social morals, among which the Confucianism doctrines are in dominance in China.

From a historical perspective, however, this distinction is not necessarily a black-and-white one. In ancient China, social order was maintained by clans at the local level and by the state government at the central level through a number of laws and moral codes. ${ }^{7}$ Confucian doctrines played out not only 'in the ritual practice of the people, in the everyday life of the family, [and] in the moral education of peasants and elite alike' but also 'in the administration of the state. ${ }^{8}$ This study focuses on the period following the late Qing Dynasty as it was in that period that the state and its legal system started the process of modernisation, and the current legal regime came into being. Because of modernisation, legal norms and social norms have been gradually separated not only in form but also in enforceability.

A few notes about the subject of both social and legal norms in this study are necessary. This article focuses on criminal reconciliation, a form of alternative dispute resolution in the field of criminal justice. It refers to a mechanism used during the administration of criminal justice that permits offenders and victims to reach a mutual understanding of a criminal act and its consequences through direct or indirect communication. It also permits parties to settle their civil disputes by means of apology, compensation and so on. Private settlement will not necessarily terminate criminal litigation, but it will act as a mitigating factor in judicial decisions. Given that the people's procuratorates（人民 检察院, China's Public Prosecution Service) follow the principle of legality (or mandatory prosecution) instead of the principle of expediency in the current legal system, the most common situation is that offender-victim reconciliation acts as a mitigating factor in judges' decisions.

Different terms have been used for this type of dispute resolution. Compared with 'mediation' (调解), 'criminal reconciliation' (刑事和解) is a relatively new concept. From a linguistic perspective, 'mediation' and 'reconciliation' are slightly different. 'Mediation' emphasises the procedure used to reach an agreeable solution, especially the use of a 'neutral third party', while 'reconciliation' focuses on the consequences of 'the restoration of har-

5. M. Feeley, 'The Concept of Laws in Social Science: A Critique and Notes on an Expanded View', 10 Law \& Society, 497, at 498 (1976).

6. M. West, 'Legal Rules and Social Norms in Japan's Secret World of Sumo', 26 The Journal of Legal Studies 165, at 167 (1997).

7. See Max Weber's analysis on the self-governance of villagers in ancient China in M. Weber, The Religion of China, translated and edited by H.H. Gerth (1951).

8. D. Gardner, Confucianism: A Very Short Introduction (2014), at 87. 
mony' between parties in conflict. ${ }^{9}$ Despite this, the essence of mediation and reconciliation - settling conflicts between disputants - is similar. In fact, criminal reconciliation does not exclude situations in which private persons, semi-official institutions such as the People's Mediation Committee (PMC), and criminal justice authorities such as police, prosecutors and judges act as mediators. Given these considerations, the terms 'reconciliation' and 'mediation' can be used interchangeably in this article as long as the mechanism in question satisfies the description mentioned previously.

The article consists of six parts including the Introduction. In the second part, the Confucian-oriented social norms regarding dispute and dispute resolutions in China are examined, with the purpose of exploring the social and political roots of the popularity of Confucianism. Confucianism doctrines matched the demands of an agricultural economy and centralised imperial government, and therefore became desirable for the emperor. Those doctrines, on the other hand, further shaped the Chinese aversion to litigation and preference for reconciliation. The third part examines the evolution of law in terms of criminal reconciliation since the early $1900 \mathrm{~s}$. It also provides a brief introduction to the current criminal reconciliation system. By comparing conventional social norms and the evolution of law, two waves of intermediate divergence can be observed. The fourth part discusses the backgrounds and the actual effect of legal norms in these two waves and identifies three key similarities between them. The fifth part examines the two waves of divergence between law and conventional social norms regarding criminal reconciliation to better explain its resurgence in legal norms in the twenty-first century. Based on this comparison, the final part further explores the position of criminal reconciliation in today's criminal justice system in China.

\section{Conventional Social Norms Regarding Disputes and Dispute Resolution in China}

Before examining the evolution of law on criminal reconciliation as well as its interaction with social norms, one needs to gain a general understanding of the traditional Chinese perspectives on dispute and dispute resolution, which are deeply shaped by Confucian doctrines, especially the concept of 'harmony'. ${ }^{10}$ 'Harmony', in Confucian understanding, means 'an orderly combina- tion of different elements, by which a new unity comes into being'. ${ }^{11}$ This new unity brings a state of peace and stability to the relationships between human beings and nature, between different hierarchies of society and between individuals. ${ }^{12}$ In this sense, a harmonious society does not eliminate controversies but instead maintains them to a manageable extent and solves them in effective ways; evaluation of the effectiveness of these measures is more oriented towards collectivism rather than individualism.

The popularity of 'harmonious society' in China has deep political, economic and cultural roots. As Robert Ellickson once commented, '[m]embers of tight social groups ... informally encourage each other to engage in cooperative behavior'. ${ }^{13}$ The agricultural economy in ancient China led to appropriately stable and tight social units such as villages and clans, featuring close interpersonal connections and favouring tranquil, self-sufficient, peaceful and stable (安、足、静、定) social relationships. ${ }^{14}$ Traditionally, Chinese viewed disputes and litigation as impeding on such social relationships, which would in turn undermine agricultural production as well as the commonwealth in general - 'the more frequent the litigation is, the more barren the field is; the more barren the field is, the more empty the barn is; the more empty the barn is, the poorer the nation is'. ${ }^{15}$ After Dong Zhongshu's development of Neo-Confucianism during the Western Han Dynasty, these understandings of harmony were transformed into the concept that 'humans and Heaven are of one species' (天人合一). ${ }^{16}$ Human behaviour, either good or evil, would in this context arouse a corresponding response from Heaven, and thus there is a moral demand that individuals cultivate their virtues and conscientiously maintain a harmonious relationship with others.

However, the maintenance of a stable and tranquil social order was not an easy task for the ancient Chinese government. Following the Qin Dynasty (221-207 B.C.), China gradually developed into a unified state with a vast territory, complex terrain and diverse ethnic groups, which, as Weber commented, led to challenges in maintaining social control:

The paucity of imperial administration actually meant that the Chinese in town and country 'governed themselves'.... During the Middle Ages the Chinese administration repeatedly sought to shift to liturgical ways of providing for public needs.... Like all far flung patrimonial states with undeveloped techniques of communication the scope of adminis-

11. Gardner, above n. 8, at 171

12. See X. Yao, An Introduction to Confucianism (2000).

13. Ellickson, above n. 1, at 167.

14. M. Qian, 中国文化史导论 (Introduction to the History of Chinese Culture) (2001), at 4 .

15. The original expression is '讼狱繁则田荒, 田荒则府仓虚, 府仓虚则国贫' See 韩非子.解老 (Hanfeizi: Explaining Laocius).

16. Y. Su，春秋繁露义证 (Interpretations on Chunqiu Fanlu) (1992), at 341. For Dong Zhongshu's reform of Confucianism, see M. Loewe, Dong Zhongshu: A 'Confucian' Heritage and the Chunqiu Fanlu (2011). 
trative centralization characteristically remained very limited. ${ }^{17}$

These geographical characteristics created tension between central and local governing bodies regarding power distribution. It further urged the emperor to find alternative ways to keep the nation together and to resolve the destabilising factors in the country. Under the influence of Confucianism, patrimonialism ${ }^{18}$ and the traditional clan acted as buffer layers as well as an agency between the governor and the governed. ${ }^{19}$ By emphasising harmonious relationships in the family and in local communities, the imperial government centralised state power by decentralising its administration.

Given these factors, traditional Chinese society generally discouraged direct confrontation between disputants, especially in the form of formal litigation - a litigationaverse (厎讼) attitude. ${ }^{20}$ This is reflected in Confucius' statement that 'in hearing litigations, I am like any other body. What is necessary, however, is to cause the people to have no litigations'. ${ }^{21}$ Influenced by this attitude, local governments adopted low litigation rates as a key index of good governance, on the one hand, while deeming litigation and its associated disputants to be disgraceful, on the other. ${ }^{22}$

In this context, private and informal victim-offender reconciliation gradually developed into one of the major dispute resolution methods, which was praised and promoted by both the government and its citizens. ${ }^{23}$ Local self-government organisations, such as the three noble elders (三老) in the Han Dynasty (202-220 B.C.), the Li-jia elders (里甲老人) in the Ming Dynasty (1368-1644) and self-governance based on rural agreement (乡约自治) in the Qing Dynasty (1636-1911), ${ }^{24}$ were developed to mediate disputes in the village or clan insofar as the fundamental interests of state or imperial power were not undermined. Except for extremely serious crimes such as homicide and treason, the question of whether to submit a dispute to local government depended on the disputants' decisions. After a case

17. Weber, above n. 7 , at 16

18. Here the term 'patrimonialism' is used in Weber's version, which refers to a traditional domination centred on top-down family structures, especially on the authority of fathers within families.

19. B. Liang, The Changing Chinese Legal System, 1978-Present (2008), at 69-70.

20. See T. Zhang, 'Why the Chinese Public Prefer Administrative Petitioning over Litigation', 3 Sociological Study 139 (2009). In this article, the author explained the relationship between the Confucian doctrines and how such a relationship influences people's choice in solving disputes in China.

21. The original expression is '听讼, 吾犹人也。必也使无讼乎'. See 论语 .颜渊 (The Analects of Confucius -Yan Yuan).

22. See Q. He, “泛讼与厌讼的历时考察 : 关于中西方法律传统的一点思考 (Historical Review on Pro-Litigation and Anti-Litigation: Comparison between Western and Chinese Legal Traditions)', 3 法律科学 (Legal Science) 10 (1993).

23. See L. Ge, ‘中国古代刑事和解探析 (Exploration of Criminal Reconciliation in Ancient China)', 1 刑事司法论坛 (Criminal Justice Forum) 145 (2008)

24. X. Wu, '不可回避的存在：解读中国古代社会刑事和解 (An Inevitable Existence: On the Criminal Reconciliation in Ancient China)', 3 政法论 坛 (Tribune of Political Science and Law) 39, at 39 (2008). entered into formal procedure, local officials would normally refrain from either mediating the case directly or banning private reconciliation. It was therefore common for cases to end without adjudication, even though they had entered the official litigation process. ${ }^{25}$

\section{Evolution of Law on Criminal Reconciliation Since the Late Qing Dynasty}

Today's criminal justice system in China can be traced back to the legal reforms of the late Qing Dynasty, which directly led to transitions in the mode of criminal litigation. ${ }^{26} \mathrm{By}$ referring to the experience of foreign legal systems, Shen Jiaben and Wu Tingfang, the leading reformers at that time, drafted the first modern criminal procedure code (大清刑事民事诉讼律草案) in $1905 .^{27}$ Combined with other implementing documents, especially the Formulation of Adjudication System in Daliyuan (大理院审判编制法) of 1906 and the Experimental Regulations for Adjudicates below Higher Courts (高等以下各级审判庭试办章程) of 1907, the 1905 draft established a state monopoly on solving criminal disputes. Crimes, minor or serious, were no longer regarded as private disputes, and private victim-offender reconciliation was explicitly banned in public prosecution cases. $^{28}$

Before the emperor could validate the draft, the Qing Dynasty was overthrown by uprisings across the country. ${ }^{29}$ China entered the Republican period (1912-1949) under the leadership of the Kuomingtang (KMT). Despite the death of the Dynasty, the essence of the $1905 \mathrm{draft}$, as well as the negative attitude towards criminal reconciliation, was inherited by the Criminal Procedure Code of the Republic of China (中华民国刑事 诉讼条例) in 1928 and 1935. ${ }^{30}$

The trend of foreclosing criminal reconciliation was reversed, however, with the change of party leadership in 1949, when today's People's Republic of China was founded. The Chinese Communist Party (CCP) showed a strong preference for mediating disputes during both the War of Resistance against Japan (1937-1945) and the Liberation War (1945-1949). For instance, according to

25. See P. Huang，清代的法律、社会与文化 : 民法的表达与实践 (The Law， Society and Culture of Qing Dynasty: Expressions and Practices of Civil Law) (2001)

26. For a detailed discussion on the history of Late Qing legal reform, see S. Huan, 'Shen Jiaben and the Late Qing Legal Reform (1901-1911)', 30 East Asia 121 (2013); J. Cheng, Chinese Law in Transition: The Late Ch'ing Law Reform, 1901-1911 (1983).

27. Before this draft, there was a combined draft procedural code for criminal and civil litigations (大清刑事民事诉讼律草案) in 1905

28. This draft distinguished between private prosecution and public prosecution, and limited the former to petty offences. It also combined criminal and civil litigations in the same code, though in different chapters.

29. The last Emperor Pu Yi (溥仪) announced his abdication on 12 February 1912.

30. See Z. Xie，中华民国立法史 (下) (History of Legislation in the Republic of China, Volume II) (1999). 
the 1943 CCP Regulations on Mediation in Civil and Criminal Cases in SNG (陕甘宁边区民刑事案件调解 条例, 1943 Regulations), offenders and victims could reconcile in all criminal cases except those involving serious crimes and crimes infringing upon public interests. ${ }^{31}$ The 1943 Regulations were revised in 1946, and because of the risks of corruption and abuse of judicial power, criminal reconciliation was restricted to cases that 'involve slight injuries due to rush impulse or negligence when the public has no objection to reconciliation'. ${ }^{32}$ After 1949, the new government followed the old practice in solving disputes, and the 1954 General Rules on PMC (人民调解委员会暂行组织通则, 1954 PMC Rules) explicitly approved mediation in minor criminal cases (Art. 3). ${ }^{33}$

From 1966 to 1976 , the entire legal system was in paralysis because of the Cultural Revolution. The atrocities against human rights during that period warned succeeding governments about the arbitrariness of the rule of human and encouraged them to promote the authority of law. ${ }^{34}$ The government started formalisation and professionalisation in the criminal justice system, accepting concepts such as 'rule of law', 'protection of human rights' and 'judicial independence'. ${ }^{35}$ Pursuant to this trend, the 1954 PMC Rules were revised in 1989 to remove the PMC's authority to mediate minor criminal cases. ${ }^{36}$ The reform moved even further in the 1996 revisions to the CPL (1996 CPL) that once again eliminated criminal reconciliation from all public prosecution cases.

At the beginning of the twenty-first century, criminal reconciliation began to resurge. ${ }^{37}$ The movement began with local judicial institutions and then gradually obtained support from the central government. ${ }^{38}$ In 2007, the Supreme People's Procuratorate (SPP) issued Several Opinions on the Application of the Criminal Policy of Tempering Justice with Mercy in Prosecution
(关于在检察工作中贯彻宽严相济司法政策的若干 意见, 2007 SPP Opinions), requiring local people's procuratorates to 'improve research on criminal reconciliation'. Simultaneously, the third Five-Years' Outline for Reform of the People's Court (人民法院第三个五年 改革纲要, 2009-2013) of the Supreme People's Court (SPC) listed criminal reconciliation as a major reform. ${ }^{39}$ Through all these efforts, in 2012, criminal reconciliation was legitimised by the 2012 CPL as an officially acknowledged form of dispute resolution. ${ }^{40}$

The current legal regime concerning criminal reconciliation is mainly regulated by Articles 277-279 of the 2012 CPL. ${ }^{41}$ According to these Articles, offenders and victims can reconcile their disputes in two types of cases. The first type refers to cases that satisfy the following three conditions: (1) the case must be caused by disputes among civilians (民间纠纷); (2) it must be concerned to a crime stipulated by Chapters 4 and 5 of the 1997 CL $^{42}$ and (3) it should carry a maximum sentence lower than three years' imprisonment. The second type refers to negligent crimes with a maximum sentence lower than seven years' imprisonment, except for duty-related crimes. Offenders who had been convicted of intentional crimes within five years prior to the current conviction are disqualified.

For the qualified cases, a reconciliation agreement can be reached if the offender (1) shows sincere remorse for the crimes and (2) receives the forgiveness of the victim by means of compensation, apology or other measures (Art. 277). After reconciliation, disputants are normally required to provide a written agreement wherein the offender expresses remorse and agrees to compensation, and the victim agrees explicitly with the criminal justice
31. Art. 2 of the 1943 Regulations stipulated that crimes such as 'against the internal security of the State, treason, homicide, banditry, extortion, violation of governmental regulation, disruption of public order, corruption, obstructing an officer in the discharge of duties, interference with voting, and escape' could not be reconciled.

32. See G. Tang, '陕甘宁边区人民调解制度述论 (Comments on People's Mediation in SGN)', 4 甘肃政法学院学报 (Journal of Gansu Political Science and Law Institute) 51 (1993).

33. Art. 3 stipulated 'the task of the Committee is to reconcile general civil disputes and slight criminal offences, and to promote legal promulgation and education through mediation'.

34. For the history of the Cultural Revolution and its relationship with China's modernisation, see T.B. Gold, 'After Comradeship: Personal Relations in China since the Cultural Revolution', 104 The China Quarterly 657 (1985)

35. Regarding China's judicial reforms related to the rule of law, see R. Peerenboom, China's Long March toward Rule of Law (2002); A. Dicks, 'The Chinese Legal System: Reforms in the Balance', 119 The China Quarterly 540 (1989).

36. See 人民调解委员会组织条例 (Organic Regulations on People's Mediation Committee), issued and validated on 5 May 1989. Hereinafter the 1989 PMC Regulations

37. This is a trend that has emerged not only in the criminal justice system but also in the entire legal system in China. For a detailed analysis on this topic, see C.F. Minzner, 'China's Turn against Law', 59 The American Journal of Comparative Law 935 (2011).

38. For the resurging process, see Pei (2014), above n. 4
39. 人民法院第三个五年改革纲要 (2009-2013) (The Third Five-Years' Outline for Reform of the People's Court), 法发 [2009] 14 号 (Fafa [2009] No.14), issued on 23 February 2009, available at: <http://news. xinhuanet.com/legal/2009-03/26/content_11074127.htm> (last visited 28 August 2014).

40. In the $2012 \mathrm{CPL}$, there are four special procedures described in part 5 ('Special Procedures'): procedures for juvenile crime; procedures for reconciliation between parties in public prosecution cases; procedures for the confiscation of illegal earnings in cases where the suspect or defendant has absconded or died; and compulsory medical procedures for mentally ill persons legally exempted from criminal liability.

41. For a more detailed introduction of criminal reconciliation in the current criminal proceedings, see 'Restoration Agreement' in Chapter III, in W. Pei, Criminal Procedural Agreements in China and England and Wales (2015), at 84-110.

42. Chapter 4 of the $1997 \mathrm{CL}$ regulates crimes infringing personal rights and citizens' democratic rights, and Chapter 5 pertains to crimes encroaching on property. Most crimes stipulated in these two chapters do not violate social or collective benefits directly, where victims are the major group who suffer from these crimes. 
authorities' lenient decisions. ${ }^{43}$ Based on that agreement, the police can suggest that the public prosecutor treats the suspect with leniency, the public prosecutor can either drop charges for extremely minor offences or make a sentence proposal to the court, and the court can impose lenient sanctions on the defendant (Art. 278).

\section{Two Waves of Marginalising Criminal Reconciliation in} Law

By examining the development of law on criminal reconciliation since the late Qing Dynasty, it can be observed that despite the traditional culture of promoting reconciliation and discouraging litigation, the legislator's attitude towards criminal reconciliation was not consistent. The analysis previously mentioned shows that convergence and divergence between law and conventional social norms proceeded alternately and that there were at least two waves of marginalisation of criminal reconciliation with respect to legal norms: one lasting from the late Qing Dynasty to 1949 and the other lasting from the Cultural Revolution to just before the beginning of the twenty-first century.

\subsection{First Wave Since the Late Qing Dynasty}

As part of the process of reforming the entire legal system in China, the first wave of marginalising criminal reconciliation was carried out in the context of a vast decline and fall of the state. From the domestic perspective, along with the onset of local rebellions such as the Taiping Rebellion (太平天国运动, 1851-1864) ${ }^{44}$ and the Boxer Rebellion of 1900 (义和团运动), ${ }^{45}$ the central government's control over society was continually impaired. On the international level, China's defeat in a series of wars with Western nations ${ }^{46}$ provoked a

43. This requirement is not in the 2012 CPL but in the interpretations or detailed regulations issued by the SPC, SPP and Ministry of Public Security: Art. 326 of 公安机关办理刑事案件程序规定 (Procedural Regulations for Public Security Organs on Solving Criminal Cases, the 2012 MPS Regulations)，公安部令第 127 号 (Gonganbu Ling No. 127), issued on 3 December 2012 and validated on 1 January 2013; Art. 516 of 人 民检察院刑事诉讼规则 (试行) (Regulations for People's Procuratorate on Criminal Procedure [Trial Implementation], the 2012 SPP Regulations)，检释 [2012] 第 2 号 (Jianshi [2012] No. 2), issued on 22 November 2012 and validated on 1 January 2013; Art. 501 of 最高人民法院 关于适用《中华人民共和国刑事诉讼法》的解释 (SPC's Interpretation of Several Issues Concerning the Implementation of the Criminal Procedure Law of the People's Republic of China, 2012 SPC Interpretations), 法释 [2012] 第 21 号 (Fashi [2012] No. 21), issued on 20 December 2012 and validated on 1 January 2013

44. For the social backgrounds of the Rebellion, see T. Reilly, The Taiping Heavenly Kingdom: Rebellion and the Blasphemy of Empire (2004).

45. See L. Bodin and C. Warner, The Boxer Rebellion (1979).

46. The main wars include the First Opium War of 1840-1842, the Second Opium War of 1857-1860, the Russia's Invasion in 1871, the Sino-Japanese War of 1894-1895 and the allied forces seizure of Peking in 1900. 'scramble for concessions' within China's territory, significantly undermining state sovereignty. ${ }^{47}$

Against such backgrounds and with the purpose of the Dynasty's salvation, an intellectual ferment ${ }^{48}$ began to take shape, generating a movement for political and institutional reform that commenced at the end of 1890s. ${ }^{49}$ On 29 January 1901, the Guangxu Emperor issued an edict blaming the decline of the Dynasty on the suffocating constraints of convention and rigid regulations. ${ }^{50} \mathrm{By}$ referring to the experiences of other legal systems, especially those of Japan, ${ }^{51}$ the edict further concluded that, to revive the Dynasty, it was necessary to learn from Western experience to remove those constraints. ${ }^{52}$

From a more pragmatic perspective, transplanting foreign criminal justice rules at that time was directly motivated by the aim of preserving the integrity of state jurisdiction, especially over foreign-related cases. Since China's defeat in the 1840 s, foreign invaders began to deny China's jurisdiction over foreign-related cases through unequal treaties. A typical example was the establishment of the Mixed Court (会审公廨) in 1868 in Shanghai. ${ }^{53}$ In the 1905 memorial to the Throne, Shen Jiaben and Wu Tingfang also mentioned the phenomenon in which foreigners frequently denied China's jurisdiction by complaining about its decivilisation, such as heavy and cruel sanctions, over-broad discretion and arbitrariness. ${ }^{54}$ With foreign military forces as backup, this rejection of jurisdiction paralysed the enforcement of law. Transplanting foreign laws would to some extent avoid such excuses. ${ }^{55}$

47. See S. Jones, 'Dynastic Decline and the Roots of Rebellion', in J. Fairbank (ed.), The Cambridge History of China, Volume 10 (1978) 107.

48. 'Intellectual ferment' refers to intellectual preparation and breeding of social events. See, for instance, M. Huang, 'Intellectual Ferment for Political Reforms in Taiwan, 1971-1973', 51 Pacific Affairs 122 (1978).

49. About the Hundred Days reform movement, which was the climax of the ferment, see K. Hsiao, A Modern China and a New World,: K'ang Yu-wei, Reformer and Utopian, 1858-1927 (1975); L. Kwong, A Mosaic of the Hundred Days (1984).

50. The original expression is '我中国之弱, 在于习气太深, 文法太密'. See The First Historical Archives of China，光绪朝上谕档，第二十六册 (Archives of Edicts issued by Guangxu Emperor, Volume 26) (1996), at 460-2.

51. For a long history, Japan had been a tributary to China. After the institutional, political and technological changes in the Meiji Reform of 1868, however, Japan greatly increased its national strength and defeated China in the first Sino-Japanese War, which was appalling to the Qing government. In the following years, legal reformers in China started to explore the reasons behind Japan's success as well as their adaptability to China. See J. Yang, 清末变法与日本 (Late Qing Legal Reform and Japan) (2010).

52. The First Historical Archives of China, above n. 50, at 460-2.

53. The Mixed Court, which consisted of Chinese and foreign adjudicators, had special jurisdiction over civil or criminal cases happened in the Shanghai concession or those involving foreigners. The Court was abolished in 1927. For an introduction of the Mixed Court and discussion on its erosion of China's sovereignty, see Y. Gan, '上海会审公廨之研究 (Research on the Shanghai Mixed Court)', (first published on Taiping Newspaper (太平导报) in May 1926), in Q. He and X. Li (eds.), 民国 法学论文精粹 : 诉讼法律篇 (Selected Archives of Legal Studies in the Republican Period: The Volume of Procedure Law) (2004) 179.

54. H. Gao (ed.), 《大清新刑律》立法资料汇编 (Archives of Legislative Materials of the Criminal Code of the Qing Dynasty) (2013), at 6.

55. Ibid. 
In sum, the ban on informal and private reconciliation in criminal cases at that time was supported by three major fulcrums. First, it followed the Western model of criminal justice, featuring a state monopoly on penal power and the rejection of private negotiability. Second, it restated the state's sovereignty over all criminal disputes that occurred within its territory, which naturally included foreign-related cases. Finally, and most importantly, it reflected the ruling class' retrospection on the 'family-state' model of governance and the attempt to reinforce power centralisation by removing the agency of conventional social control, the patriarchal clan system.

Despite these three fulcrums, however, studies have shown that this reform had a very limited impact on actual practice. In their research on the judicial archives in Longquan County (龙泉县) from 1929 to 1949, for instance, Hu Ming and Zhang Jian noticed that criminal reconciliation still constituted a fairly large proportion of criminal justice practice. ${ }^{56}$ According to the study, the County preserved the files concerning 245 criminal cases, among which 102 cases were reconciled, a proportion of $41.6 \% .{ }^{57}$ The modern legal system imported during this period was similar to 'oil floating on the water', ${ }^{58}$ and, in Muhlhahn's words, 'the Republic still had to accommodate Qing criminal law and the traditional values that remained in place especially in rural areas'.59

\subsection{Second Wave after the Cultural Revolution}

The second wave of divergence between law and conventional social norms on criminal dispute resolution happened in the late 1970 s after the Cultural Revolution. Ten years of social upheavals had resulted in profound consequences. The first consequence was confusion in both social norms and law. On the one hand, by attacking traditional Chinese culture, especially in the 'Criticize Lin and Criticize Confucius' campaign (批林 批孔), ${ }^{60}$ the Revolution seriously challenged the Confucian-oriented social order. On the other hand, the legis-

56. See M. Hu and J. Zhang, “转型与承续 : 民国时期的刑事和解 (Transformation and Inheritance: The Criminal Mediation in the Period of the Republic of China)', 4 浙江大学学报 (Journal of Zhejiang University) 1(2013).

57. Ibid., at 3 .

58. D. Pan, ‘中国近代以来法律文化发展考察 (Study on the Legal Cultural Development Since 1840 in China)', 2 社会学研究 (Sociological Studies) 116 (1989). See also, Zeng, above n. 2.

59. Ibid., at 59

60. Mao launched the campaign in 1973 after the 1st Plenary Session of the 10th CCP Central Committee, encouraging public criticism against Confucius and Confucianism and using Marxism and Maoism as replacement. This campaign did not directly target at the conventional Confucianism or Confucius himself, but at Lin Biao (林彪) and Zhou Enlai (周恩来) by innuendo and insinuation. Even so, it still led to a social movement against traditional social morals, calling for the abolishment of Confucianism doctrines. In this movement, 'social harmony' was replaced by confrontation between man and god, and between individuals. See A. Gregor and M. Chang, 'Anti-Confucianism: Mao's Last Campaign', 19 Asian Survey 1073 (1979); K. Forster, 'The Politics of Destabilization and Confrontation: The Campaign against Lin Biao and Confucius in Zhejiang Province, 1974', 107 China Quarterly 433 (1986) lative process that had been initiated in 1950s was interrupted, leading to a land without law for a decade.

The second consequence was a power vacuum. Under slogans such as 'sweep away all cow-demons and snakespirits' (横扫一切牛鬼蛇神) ${ }^{61}$ and 'smash public security organs, procuratorates and courts' (砸烂公检法), ${ }^{62}$ state functionaries were generally paralysed, and the central government's control over society relied heavily on Mao's personality and charisma. ${ }^{63}$ Such control, as Weber commented, 'is naturally unstable'. ${ }^{64}$ This backbone of the CCP's authority during the Revolution collapsed with Mao's death in 1976, and the new government, which was under the leadership of Deng Xiaoping, was confronted with the urgent task of finding a replacement to restore the legitimacy of the Party.

What could serve as a proper replacement? According to Weber, the fall of charismatic authority will lead to the inevitable routinisation through either traditionalisation or rationalisation, or both. ${ }^{65}$ Which to choose largely depends on the social, political and economic backgrounds at a given time. The establishment of a traditional authority normally requires bases such as 'habituation, respect for tradition, piety toward parents and ancestors, and the servant's personal faithfulness', ${ }^{66}$ which during the Cultural Revolution was seriously undermined. Instead of exploring China's legal traditions, the government under Deng's leadership sought other options, which can be observed from a series of speeches delivered by Deng. For instance, in his speech on 28 June 1979, Deng blamed societal turmoil during the Cultural Revolution on the absence of democracy and of a legal system. ${ }^{67}$ In a 1980 speech, he further argued that this absence, as well as frustrations suffered

61. 'Cow-demons and snake-spirits' at first referred to 'bourgeois experts, scholars, and academic authorities', and later it was expanded to Chinese intellectuals and 'those in power'. See 'Sweep Away All CowDemons and Snake-Spirits' in J. Guo, S. Yongyi \& Z. Yuan, Historical Dictionary of the Chinese Cultural Revolution (2006), at 272.

62. As imported from foreign legal systems, in the Cultural Revolution the judicial system was claimed to be "those in power who take the capitalist road' (走资本主义的当权派), and therefore became the target of the class struggle. See X. Yang, “砸烂公检法和清理阶级队伍 (Smash Public Security Organs, Procuratorates and Courts, and Rectify the Class Ranks)', 2 炎黄春秋 (China's History) 55 (2013).

63. See J. Andreas, 'The Structure of Charismatic Mobilization: A Case Study of Rebellion during the Chinese Cultural Revolution', 72 American Sociological Review 434 (2007). Some, however, argued that Mao's charismatic leadership had limited impact on people's behaviour. Instead of being 'true believers', most participants at that time were actually motivated by calculations of risks and rewards. See G. Wang, Failure of Charisma: The Cultural Revolution in Wuhan (1995).

64. M. Weber, Economy and Society: An Outline of Interpretive Sociology, edited by $\mathrm{G}$. Roth and $\mathrm{C}$. Wittich, translated by a number of scholars (1978), at 1114.

65. Ibid. Charismatic authority, legal (or rational) authority and traditional (or coercive) authority are Max Weber's tripartite classification of authority, emphasising the source of legitimacy of the authority. See T. Waters and D. Waters (eds. and trans.), Weber's Rationalism and Modern Society (2015), at 59-72.

66. See above n. 64 , at 1118 .

67. D. Xiaoping, ‘民主和法制两手都不能削弱 (Strengthen Democracy and Legal System Simultaneously)', in CCP Editorial Committee on Party Literature, 邓小平文选 (第二卷) (Selected Works of Deng Xiaoping, Volume 2) (1994), at 189. 
during the history of the CCP, had mainly resulted from ingrained but outdated patriarchalism. ${ }^{68}$

This preference for rationalisation was particularly relevant to the third consequence of the Revolution - that is a wide-spread re-evaluation of human rights protection. It is easy to ascertain the features of Chinese society during the Revolution by referring to keywords in the relevant literatures: 'turmoil', 69 'tumult', 70 'purge and holocaust' ${ }^{71}$ and so on. In the field of criminal justice, the principle of nulla poena sine lege did not apply. Torture and private sanctions were allowed or even applauded; court trials were replaced by violent and humiliating 'struggle sessions'; and conviction and sentencing were decided without any procedure. ${ }^{72}$

Taken together, these consequences gave birth to the 1979 CPL, which served two major purposes. As a product of rationalisation, its first function was to rebuild the state authority by emphasising the monopoly power of the judicial system in solving criminal cases. Its second function was to protect people (人民) by avoiding the misuse of criminal sanctions. ${ }^{73}$ With respect to the first function, private settlement was deemed to infringe upon the judicial system's monopoly and create extra-legal exceptions. With respect to the second, criminal reconciliation was viewed as ideologically improper, as what was involved in criminal justice were 'contradictions between ourselves and the enemy' (敌我矛盾). The $1996 \mathrm{CPL}$ inherited the structure and the guiding ideology of the 1979 CPL, with its revisions mainly focused on refining old rules and strengthening human rights protections.

What about dispute resolution in practice? In the 1980s and the $1990 \mathrm{~s}$, mediation or reconciliation rarely appeared in criminal law studies. However, the work of both Fei Xiaotong and $\mathrm{Su} \mathrm{Li} \mathrm{has} \mathrm{shown} \mathrm{people's} \mathrm{confu-}$ sion regarding formal dispute resolution in rural areas. ${ }^{74}$ Local legal officials were also occasionally consulted by disputants about the possibility of solving criminal cases

68. See D. Xiaoping，“党和国家领导制度的改革 (Reforms on CCP and State Leadership)', in ibid., at 320.

69. See R. King, S.T. Zheng \& S. Watson (eds.), Art in Turmoil: The Chinese Cultural Revolution (1966-76) (2010).

70. See J. Daubier, A History of the Chinese Cultural Revolution (1974).

71. See M. Law (ed.), The Chinese Cultural Revolution Reconsidered: Beyond Purge and Holocaust (2003).

72. These features are well presented by Gao Yuan's book, in that the author recorded some cases in detail with respect to the arbitrary use of violence. See Y. Gao, Born Red: A Chronicle of the Cultural Revolution (1987)

73. See G. Wang, “一部社会主义的刑事诉讼法典 (A Criminal Procedure Code of Socialism)', 4 北京大学学报 (Journal of Peking University) 10 (1979).

74. See X. Fei, 乡土中国 (Rural China) (2008); L. Su, 送法下乡 : 中国基层司 法制度研究 (Deliver Knowledge of Law to the Rural Areas: Research on the Legal System of China at the Basic Level) (2000). One should be aware of the importance of studying legal enforcement in these rural areas in China. According to World Bank's statistics, the proportion of rural population in China was around 70\% in the 1990s and 50\%-60\% in the 2000s. Last year, the rate was still as high as $47 \%$. Given such a large population, the quality of legal enforcement among them is directly and significantly influential to that of the entire legal system. Statistics are available at: <http://data.worldbank.org/indicator/SP.RUR. TOTL.ZS> (last visited 12 November 2015). privately. ${ }^{75}$ Since the 2000 s, studies on criminal reconciliation have gradually increased, and their focus has shifted from rural areas to cities. ${ }^{76}$ For instance, from 2006 to 2008, Song Yinghui conducted systematic empirical research on criminal reconciliation in seven district people's procuratorates in four large cities, and the reconciliation rate varied between $0.5 \%$ and $4.4 \% .{ }^{77}$ These studies show that criminal reconciliation is not applied on a massive scale.

\subsection{Comparison between Two Waves of Legal} Norms and Social Norms' Divergence

At first glance, the two waves of divergence between law and conventional social norms are distinguished in several aspects, such as direct motivations (opposition to foreign invaders vs. restoration of domestic order), the dominant ideology of the government (imperialism vs. communism), the social class supporting reform (intellectual elite vs. grassroots and intellectual elite) and the subsequent social environment (war vs. peace). These distinctions, although crucial to interpreting reform strategies and tactics in detail, can explain neither the fundamental reasons behind the divergence that is common to both the two waves nor the consequences of such divergence, especially the enforceability of law. In addition, they are of little help in understanding the resurgence of criminal reconciliation in the 2012 CPL. A more contributive perspective is therefore required to find similarities in the midst of such differences.

At first, it is not difficult to notice that both waves of divergence occurred during times of social turbulence when serious challenges were being mounted to state authority. At those times, it was urgent for the government to re-establish its legitimacy, to centralise state power and, based on that, to restore social order. Against this background, a common and pragmatic approach adopted by the late Qing government and the

75. See e.g. Cangshan People's Procuratorate, “重伤案件能否调解 (Can Assault Cases that Resulted in Serious Injury Be Mediated?)', 1 中国 民营 (China Non-Governmental) 53 (1999); W. Lu， ‘已调解赔偿的刑事 案件可追究行为人的刑事责任 (Suspects Can Be Prosecuted Regardless of Mediation and Compensation)', 3 法学杂志 (Law Science Magazine) 29 (1996).

76. See W. Fu, '刑事和解的实证分析 (Empirical Research on Criminal Reconciliation)', 14 国家检察官学院学报 (Journal of National Prosecutors College) 60 (2006) (research in Yuhua District People's Procuratorate in Hebei Province); L. Wang and Y. Li, ‘刑事和解工作机制实证研究 (Empirical Research on the Working Mechanism of Criminal Reconciliation)', 26 政法论坛 (Tribune of Political Science and Law) 22 (2008) (research on the satisfaction rate of disputants in Chaoyang People's Procuratorate in Beijing); C. Fan and J. Ai, '刑事和解管见和实证考量 (Opinions and Empirical Examination on Criminal Reconciliation)', 2 中国司法 (Justice of China) 24 (2010) (research in Haidian District People's Court in Beijing); Y. Zhang et al, “刑事和解中检察机关能共司法的 制度选择 (Legal Regime on Criminal Reconciliation for People's Procuratorate under Active Judicature)', 11 政治与法律 (Political Science and Law) 155 (2010) (research in six district people's procuratorates in Shanghai); Y. Zhang and X. Lu, '公安部门刑事和解体系实证研究 (Research on Criminal Reconciliation in Public Security Organs)', 26 江苏警官学院学报 (Journal of Jiangsu Police Office College) 140 (2011) (research in local PSO in Jiangsu).

77. See Y. Song, ‘我国刑事和解实证分析 (Empirical Research on Criminal Reconciliation in China)', 5 中国法学 (China Legal Sciences) 123 (2008). The rate is consistent with that obtained by the author in her interviews with local legal officials. See Pei (2014), above n. 4. 
CCP was to remove agency in the administration of power by 'strengthening and institutionalizing mechanisms of administrative and organizational controls' ${ }^{78}$ Criminal and penal laws in this context were used by the state to 'define and enforce a new set of state-sponsored social values' and, hopefully, to 'guard and enhance its authority'. ${ }^{79}$ Criminal reconciliation, which traditionally induced the administration of penal power of the state apparatus in a decentralised way, was undesirable.

How, then, can a proper substitution be found? Answers to this question reveal the second similarity between the two waves: the legal reforms in China during the two periods were not self-generated but consisted mainly of legal transplants. ${ }^{80}$ However, legal transplants in both periods were implemented within a short period of time and in the context of socio-political chaos. With regard to legal transplants in the first wave, $\mathrm{Ng}$ commented that 'although the government was the main driver of legal reform, government heads may not have accurately perceived the outcomes of that reform'. ${ }^{81}$ The social unrest in the following period further frustrated the systematic establishment of the corresponding state apparatus. More importantly, it impeded the internalisation process of new values among members of society. These observations are also true of the second wave, which can be better illustrated by the aforementioned gap between the legal rules and its actual effects regarding criminal reconciliation.

More importantly, when both legal reforms took place, the Chinese economic pattern and the corresponding social structure had not yet experienced a fundamental transition. This is the third similarity. Before the first wave in the $1900 \mathrm{~s}$, 'there was little of the Chinese economy ... that was not included within the agricultural sector or quite intimately connected with it' ${ }^{82}$ In the Late Qing Dynasty, reformists such as Kang Youwei had proposed modernisation in industry, commerce, transportation and communication, the fiscal system and so on. ${ }^{83}$ These economic measures, although oriented in the right direction, failed to adapt to China's special environment and, consequently, to fundamentally reform the agricultural economy and the corresponding social relationship. ${ }^{84}$

78. P. Landry, Decentralized Authoritarianism in China: The Communist Party's Control of Local Elites in the Post-Mao Era (2008), at 12.

79. K. Muhlhahn, Criminal Justice in China: A History (2009), at 58-59.

80. The first wave was mainly influenced by the Japanese Law. In the second wave, the 1979 CPL was a hybrid of several legal traditions. For one thing, it was in general based on the framework of the 1963 Draft of $\mathrm{CPL}$ that had imported key elements of the former Soviet Union laws. For another, it also absorbed ingredients of Western laws, especially those concerning human rights protections. The $1996 \mathrm{CPL}$ did not change the structure fundamentally but imported strong adversarial features from common law legal system. For the influence of foreign laws on the evolution of Chinese criminal procedural rules, see $\mathrm{H}$. Wu and S. Zhong, 中国刑事诉讼法典百年 (1906 年-2012 年) (A Century of China's Criminal Procedure Codes, 1906-2012) (2012).

81. M. Ng, Legal Transplantation in Early Twentieth-Century China: Practicing Law in Republican Beijing (1910s-1930s) (2014), at 1.

82. J. Fairbank and K. Liu (eds.), The Cambridge History of China, Volume II, Late Ch'ing, 1800-1911, Part 2, (1980), at 1.

83. See Hsiao, above n. 49.

84. Ibid.
With regard to the second wave, the new government had, since 1949, launched campaigns to communise or nationalise the state economy according to the model of the former Soviet Union. The latter, however, did not provide concrete and practical guidance on how to construct a communist economy. Therefore, in the $1950 \mathrm{~s}$ and the early 1960s, China experienced 'a bewildering succession of [economic] reforms ${ }^{85}$ such as the Great Leap Forward (大跃进), which led to a disastrous economic recession in the following years. ${ }^{86} \mathrm{With}$ the succession of the Cultural Revolution, there was also no systematic and stable economic reform before the second wave.

\section{Rethinking Criminal Reconciliation's Resurgence in the Twenty-First Century}

\subsection{What Has Changed and What Has Remained the Same?}

The purpose of examining the two waves of divergence between law and conventional social norms regarding criminal reconciliation is to better explain its resurgence in legal norms in the twenty-first century. To achieve this, one needs to start by assessing the changes in the social, economic and political backgrounds in the new century by comparing them with those during the two waves of divergence.

Above all, the most dramatic change is the rapid transition from a planned to a market economy. Under the slogan 'Socialism with Chinese Characteristics'( 中国特 色的社会主义), policies such as the permissive development of private enterprises, the decollectivisation of the rural commune system, the embrace of foreign investment, and the privatisation and contracting out of some state-owned industries were gradually introduced. ${ }^{87}$ These reforms triggered not only unprecedented economic growth but also profound changes in the conventional social structure in the following decades. For instance, the proportion of rural residents in 1950 in China was approximately $88.8 \%$. It took forty years for the state to decrease the rate to $73.6 \%$ (in 1990), yet it took only twenty years for it to further decrease to 50.32\% (in 2010). ${ }^{88}$ From 1979 to 2009, the urban pop-

85. M. Goldman and R. MacFarquhar (eds.), The Paradox of China's PostMao Reforms (1999), at 3.

86. Bachman described the Great Leap Forward as 'one of the most extreme, bizarre, and eventually catastrophic episodes in twentieth-century political history'. See D. Bachman, Bureaucracy, Economy, and Leaderships in China: The Institutional Origins of the Great Leap Forward (1991), at 2

87. See L. Brandt and T. Rawski (eds.), China's Great Economic Transformation (2008).

88. For the data before 2006, see Liang, above n. 19, at 102-3. For the data in 2010, see National Bureau of Statistics of China, 2010 年第六次 全国人口普查主要数据公报 (Gazette of Major Data of the Sixth National Population Census in 2010), issued on 28 April 2011, available at: <www.gov.cn/test/2012-04/20/content_2118413.htm> (last visited 19 November 2015). 
ulation grew by approximately 440 million, which is described by scholars as 'the largest [rural-urban migration] in human history'. ${ }^{89}$ According to the report of the National Health and Family Planning Commission of China (NHFPC), in 2013, the floating population ${ }^{90}$ has reached 245 million. ${ }^{91}$ Such mobility contrasts sharply with the traditional image of the Chinese - that is of ' $a$ non-migratory people'. ${ }^{92}$ In addition, the one-child policy has, to some extent, diminished family size and disintegrated traditional clans. ${ }^{93}$

It was in this context that China launched a new legal reform in the end of the $1990 \mathrm{~s} .{ }^{94}$ All three similarities between the two waves identified in the previous section have changed in today's society. First, after three decades of economic reform, the traditional agricultural economy has greatly shrunk, along with the conventional patriarchal system and close and stable inter-personal relationships. Secondly, the new reform was motivated by domestic and spontaneous demand, aimed at guiding economic growth. Thirdly, the relatively stable social environment after the 1970 s guaranteed a gradual internalisation of new legal concepts imported along with the 1979 and 1996 CPL - that is judicial independence (in a relative sense), human rights protection (also relatively) and rule of law (although this thought is often confused with that of 'rule by law').

With all these changes, emphasising the centralisation of state power appears to be neither urgent nor directly beneficial. In fact, the mismatch between the gradually decentralised state economy and stubbornly centralised government power has provoked fierce academic debate. ${ }^{95}$ As Landry commented, China's position is particularly puzzling if we consider the nature of its political institutions. Decentralization may benefit the economy, yet ... [it] corrodes authoritarianism by creat-

89. K. Chan, 'China, Internal Migration', in I. Ness and P. Bellwood (eds.), The Encyclopedia of Global Human Migration (2013) 1.

90. 'Floating population', '流动人口' in Chinese, refers to a group of people who are registered in one region and resided in another region for a certain period of time, but are not considered as part of the official census count in the region of their residence. It is related to China's residence permission system.

91. See The Floating Population Division of NHFPC，中国流动人口发展报告 2014 (Report on China's Migrant Population Development 2014) (2014).

92. See R. Skeldon, 'Migration from China', 49 Journal of International Affairs 434 (1996)

93. See S. Greenhalgh, Just One Child: Science and Policy in Deng's China (2008)

94. The symbol of the new reform was the SPC's first five-year plan of reforming people's courts (人民法院五年改革纲要)，法发 [1999] 28 号 (Fafa [1999] No. 28), issued on 20 October 1999

95. See e.g. Landry, above n. 78; F. Gul and H. Lu, Truths and Half Truths: China's Socio-Economic Reforms (1978-2010) (2011); T. Wright, Accepting Authoritarianism: State-Society Relations in China's Reform Era (2010); R. Schiere, China's Development Challenges: Economic Vulnerability and Public Sector Reform (2010). The economic prosperity appears to be exactly a product of mechanical dysfunction or malfunction of the state apparatuses, giving rise to questions such as 'does law matter'. See V. Lo, 'China's Path to Development: Does Law Matter?' in V. Lo and M. Hiscock, The Rise of the BRICS in the Global Political Economy (2014) 268; M. Faure and J. Smits, Does Law Matter? On Law and Economic Growth (2011). ing loci of power that can gradually develop into a source of political opposition..$^{96}$

The most influential wave of decay happened around the late 1980s, peaking with the Tiananmen Event in 1989. ${ }^{97}$ This event, on the one hand, led to the government's rather conservative attitude towards Western ideologies such as democracy, ${ }^{98}$ whereas, on the other hand, it 'destroyed what little belief in Marxism-Leninism was left'. 99

Against such backgrounds, the Chinese government was confronted in the late 1990s with ideological confusion in society, which put its legitimacy at stake. When economic prosperity continues apace, the risk can remain implicit and under control. However, when the precondition fails or is challenged, the tension between the monistic government and society is likely to become pointed. This is exactly what happened at the beginning of the twenty-first century when the gross domestic product (GDP) annual growth rate dropped from $14.3 \%$ in 1992 to $7.9 \%$ in 1999 , and the decrease continued in the following years. ${ }^{100}$ Meanwhile, rapid economic growth has also caused unexpected problems. The Gini efficient in China increased from 0.291 in 1981 to 0.392 in $1999 .{ }^{101}$ In 2014 , the rate reached 0.469 , indicating a serious wealth gap in society. ${ }^{102}$ In addition, in 2014, China became the second-largest economy in the world, but its ranking in the Corruption Perceptions Index issued by Transparency International was only 100. ${ }^{103}$ The most populous parts of China are exposed to serious water and air pollutions such as the notorious PM 2.5. ${ }^{104}$ Bubbles in housing prices and the unbearable cost of medical care and education have further sharpened social contradiction. ${ }^{105}$ Correspondingly, the frequency of social protests (群体性事件) has increased dramatically, some of which even caused serious confrontations between local governments and citizens. ${ }^{106}$

In this context, here again emerges the old question of how a monistic government can maintain social stability in such a large territory. With suspicion against Western ideologies and collapsing communist beliefs, the central

96. Landry, above n. 78, at 6-10.

97. See J. Fewsmith, China since Tiananmen: The Politics of Transition (2004).

98. See J. Beja (ed.), The Impact of China's 1989 Tiananmen Massacre (2011).

99. Fewsmith, above n. 97, at 9 .

100. See World Bank statistics on GDP annual growth, available at: <http:// data.worldbank.org/indicator/NY.GDP.MKTP.KD.ZG/countries/CN? page $=4 \&$ display $=$ default $>$ (last visited 20 November 2015) .

101. Data are available at: <http://data.worldbank.org/indicator/SI.POV. GINI?page=1> (last visited 19 November 2015)

102. See NBS, 2014 年国民经济在新常态下平稳运行 (Smooth Running of National Economy under 'New Normal' in 2014), available at: <www. stats.gov.cn/tjsj/zxfb/201502/t20150211_682459.html> (last visited 19 November 2015).

103. Data available at: <www.transparency.org/cpi2014/results> (last visited 20 November 2015).

104. See World Bank, Cost of Pollution in China: Economic Estimates of Physical Damages, available at: <http://siteresources.worldbank.org/ INTEAPREGTOPENVIRONMENT/Resources/China_Cost_of_Pollution. pdf> (last visited 24 November 2015).

105. See Gul and Lu, above n. 95

106. Pei (2014), above n. 4, at 215-6. 
government has shifted its emphasis from pure rationalisation to a combination of rationalisation and traditionalisation, the third option offered by Weber. ${ }^{107}$ During the past fifteen years, the central government introduced a new political goal of 'constructing socialist harmonious society' (构建社会主义和谐社会), restating the importance of maintaining harmonious relationships between individuals, between the government and people, between human beings and nature, and between China and foreign countries. ${ }^{108}$ Confucianism is propagandised as the essence of China's culture and an indispensable ingredient of the country's soft power. On the international level, a typical symbol of the government's promotion of Confucianism is the worldwide spread of Confucius institutes. ${ }^{109}$ On the domestic level, the concepts of 'family' and 'neighbourhood' and traditional moralities such as filial piety are highlighted in politics and everyday life. ${ }^{110}$

\subsection{Position of Criminal Reconciliation in}

Today's Chinese Criminal Justice System

The resurgence of criminal reconciliation in the twentyfirst century is by no means a coincidence. The changes in political ideology are reflected in the operation of the legal system. All legal institutions, including those in the criminal justice system, are required to proactively solve social disputes and promote harmonious inter-personal relationship. ${ }^{111}$ The 2012 CPL bears the corresponding task of 'safeguarding social security, resolving social conflicts, and maintaining social stability'.112

Criminal reconciliation, which can restore the harmonious relationship between offenders and victims, can contribute to requirement harmonious society. Behind it is the government's attempt to subcontract, although in a controlled manner and scope, the task of social control to local legal systems, to family and community, and to ordinary citizens.

Private dispute resolution has indeed functioned well over the past thousands of years, but can it still work today? From the previous discussion, it should be noted that while the central government is, in Deng's famous

107. Weber (1978), above n. 64 .

108. 中共中央关于构建社会主义和谐社会若干重大问题的决定 (The Decision of the CPC Central Committee on Certain Major Issues in Constructing of an Harmonious Socialist Society), on the 6th Plenary Session of the 16th Central Committee of CPC, 2006, available at: <http:// news.xinhuanet.com/politics/2006-10/18/content_5218639.htm> (last visited 16 March 2015)

109. See H. Lai, 'China's Cultural Diplomacy: Going for Soft Power', in H. La and Y. Lu (eds.), China's Soft Power and International Relations (2012), at 83-103.

110. See D. Bell, China's New Confucianism: Politics and Everyday Life in a Changing Society (2010).

111. 中共中央关于构建社会主义和谐社会若干重大问题的决定 (The Decision of the CPC Central Committee on Certain Major Issues in Constructing of an Harmonious Socialist Society), on the 6th Plenary Session of the 16th Central Committee of CPC, available at: <http://news. xinhuanet.com/politics/2006-10/18/content_5218639.htm> (last visited 16 March 2015).

112. See 关于《中华人民共和国刑事诉讼法修正案 (草案) 》说明 (Official Interpretations on the Draft of the 2012 CPL), issued on 8 March 2012, available at: <www.gov.cn/2012lh/content_2086875.htm> (last visited 25 November 2015). expression, 'crossing the river by feeling the stones' (摸着石头过河), the basis of traditional culture is also in transition. On the one hand, changes in the economic pattern and social structure mentioned previously have shaken the roots of Confucian doctrines. On the other hand, several anti-Confucian trends and the influence of communism and capitalism since the early 1900s have caused ideological confusion in society.

In the field of criminal justice, the modernisation process has established, especially since the late 1970s, a primary structure of formalised and professionalised proceedings. Criminal reconciliation can only be reintroduced within this structure as a supplement to ordinary criminal procedure. Taken from this starting point, several features of the current criminal reconciliation system can be observed.

First, reconciliation can only be conducted if the overarching tasks of criminal procedures are not violated, that is to convict the guilty, to acquit the innocent and to assign proper sanctions. This is reflected in the treatment by the 2014 SPC Sentencing Guiding Opinions on Normal Crimes (关于常见犯罪的量刑指导意见, 2014 Guiding Opinions) of defendants who have reached reconciliation agreements with victims; before any sentence discount is issued, the baseline for sentencing must be established according to the seriousness of the crime and the culpability of the defendant. Normally the discount should not exceed $50 \%$. $^{113}$

The second feature concerns the effect of reconciliation. Under the new legal regime, matters that can be reconciled through informal dispute resolution are explicitly restricted to issues such as financial compensation. Accordingly, the offender-victim agreement can only affect the arrangement of civil rights and obligations, and criminal law issues such as conviction and sentencing are strictly reserved to criminal justice agencies.

The effect of reconciliation is largely relevant to the changing role of victims in the criminal justice system, which is the third feature. Along with the modernisation of criminal justice, victims gradually have lost their dominant role in processing crimes and reconciling with offenders. In fact, one of the toughest issues in embedding criminal reconciliation in the current criminal justice system is how to situate victims and to what extent judicial decisions can be influenced by their voices.

Last but not least, criminal reconciliation under the 2012 CPL normally will not terminate criminal procedure, but will only act as a mitigating factor in legal decisions. In this way, the law has set restrictions not only on private disputants but also on criminal justice authorities.

These features weaken the ability of criminal reconciliation to absorb and process disputants' grievances and result in two phenomena regarding its implementation. The first one is that the scale of criminal reconciliation after the promulgation of the 2012 CPL is still relatively small. For instance, according to Xu Qiming's empirical

113. In extreme minor crimes, the discount can be higher, or even exemption of punishment. See Art. 10 of the 2014 Guiding Opinions. 
research in six district PSOs in Guangdong Province from January 2012 to April 2013, the reconciliation rate varied between $5 \%$ and $7 \% .{ }^{114}$ It is similar to situations in the people's courts. An empirical study of a basic people's court (a court at the lowest level) in Beijing shows that, in 2013, there were only 206 cases reconciled, constituting $6.48 \%$ of the entire caseload. ${ }^{115}$ Reconciliation was mostly applied in cases of traffic offences, crimes of assault that caused slight injuries, theft, negligent crimes and some minor economic crimes. ${ }^{116}$ The second phenomenon is that tension between criminal reconciliation and ordinary criminal proceedings provokes suspicion as to the legitimacy of criminal reconciliation. In fact, today's criminal reconciliation has been criticised for enabling the rich to 'buy their way out' (花钱买形). ${ }^{117}$ Such a critique hardly existed in the traditional Chinese legal system.

\section{Conclusions}

Criminal reconciliation in China has deep roots in Confucianism, which was in general the product of 'an agricultural society's quest for a comfortable home and a satisfying enterprise ... [and the government's quest for] social stability, concord and order' ${ }^{118}$ Either abolishing or enabling criminal reconciliation in law is merely a small part of the government's strategy to maintain legitimacy and social stability. However, any rushed departure from conventional social norms, which normally occurs during urgent political and social crises, is likely to undermine the enforceability of law.

In the past few decades, however, the conventional foundations of Confucianism have been in transition. On the one hand, its economic basis and corresponding social structure have changed, with calls for the decentralisation of state power and for democracy. On the other hand, the unitary political regime in China's vast territories remains in existence in the form of a 'partystate'. The current position of criminal reconciliation in the criminal justice system reflects the mismatch between China's economic foundation and corresponding social structure. Through this keyhole, one can observe some fundamental issues in Chinese society. At heart is the question of whether the government can adapt itself to a changed social and economic environment without abolishing the monistic political regime. Reintroducing criminal reconciliation or, more radically, reintroducing Confucian concepts in today's China reflects the government's attempt to answer that question. Is it, however, the right answer? It is difficult to assess. Even so, the Chinese government needs to be aware of three things. First, the impact of Confucian doctrines in society is weakening, and this is likely to continue in the future. Careful and prudent evaluation is required to assess the extent to which the government can continue to rely on these doctrines. Second, political decentralisation is inevitable, regardless of ownership or administration. Criminal reconciliation in the current legal regime can hardly serve the purpose of the central state power. The strategies of social control adopted by the government should be in line with, and try to adapt to, the trend of decentralisation, rather than go against it. Third, the inconsistent and pragmatic transplant of foreign legal rules that began in the 1900s has created a highly fragmented criminal justice system. The mixture of, on the one hand, domestic and foreign and, on the other, traditional and modern factors in the interaction of social norms and legal norms exists not only in criminal reconciliation but also in the context of other issues. Without careful and delicate assessment of these factors, the actual effect of legal reforms may depart from the original legislative intent.

114. Q. Xu and X. Kong, '公安机关刑事和解实证研究 (Empirical Research on Criminal Reconciliation in PSOs)', 2 中国人民公安大学学报 (Journal of People's Public Security University of China) 43 (2014).

115. The Criminal Reconciliation Research Group in Chaoyang District People's Court in Beijing，“关于法院适用刑事和解程序的调研报告 (Empirical Research Report on The Application of Criminal Reconciliation in People's Court)', 11 人民司法 (People's Judicature) 42 (2014).

116. Ibid., at $46-47$

117. See Y. Zhang，烟台首例刑事和解案引关注：会导致花钱买刑吗 (The First Criminal Reconciliation in Yantai City Drew Attention: Will It Lead to Buying Penalty), 26 March 2013, available at: <http://qd.ifeng.com/ sd/detail_2013_03/26/661668_0.shtml> (last visited 28 August 2014); 专家解读刑事和解: 明确使用标准避免花钱买刑 (Experts Comment on Criminal Reconciliation: Clarify Standards to Avoid Buying Penalty), 27 September 2012, available at: <http://news.xinhuanet.com/legal/2012 -09/27/c_123766919.htm> (last visited 13 August 2014).

118. Zeng, above n. 2 